\title{
Corporate cash management: A study on retail sector
}

\author{
Somnath Das*
}

Assistant Professor in Commerce, Rabindra Mahavidyalaya, Champadanga, Hooghly - 712401, W.B. India

\begin{tabular}{|c|c|}
\hline CHRON I CLE & A B S T RA C T \\
\hline $\begin{array}{l}\text { Article history: } \\
\text { Received December 5, } 2015 \\
\text { Received in revised format } \\
\text { March } 162016 \\
\text { Accepted May } 282016 \\
\text { Available online } \\
\text { May } 312016\end{array}$ & $\begin{array}{l}\text { Cash is the life blood of the organizations and cash management is the important aspect of any } \\
\text { organization. Corporate cash management boosts the companies from small to giant in the } \\
\text { competitive environment. In this study, we highlighted three factors of a good cash } \\
\text { management practices; namely cash conversion cycle, cash holding and credit score. Influence } \\
\text { of one factor to other help organizations manage their corporate cash more appropriately. In } \\
\text { this study, we collected data from Capitaline corporate data base of Mumbai over the period }\end{array}$ \\
\hline $\begin{array}{l}\text { Keywords: } \\
\text { Cash management } \\
\text { Cash conversion cycle }\end{array}$ & $\begin{array}{l}2002-2011 \text {. In this study we observed that due to higher credit score, companies were forced } \\
\text { to minimize their cash conversion cycle and helped them maintain lower levels of working } \\
\text { capital. }\end{array}$ \\
\hline
\end{tabular}

Cash holding

Credit score

\section{Introduction}

Generally cash is a specific form of money. From financial point of view it refers to all money items and sources that are immediately available to help pay a firm's bills. It is the most common purchasing power or medium of exchange. Cash is one of the most important elements of working capital. In modern business world, cash performs various functions. It makes possible the payment by cheque, it acts as a storage for earmarked funds. It is a reservoir from which money may be used to meet emergencies. Now a days, business uses credit instead of cash in its routine work. The use of bills, draft, credit cards, debit cards, ECS, fund transfer through internet etc. replaces the use of coin and paper currency. Cash management is the art and increasingly the science of managing a company's short-term resources to sustain its ongoing activities, mobilize funds and optimize liquidity. The most important elements of cash management are - (a) efficient utilization of current assets and current liabilities of a firm throughout each phase of business operating cycle; (b) the systematic planning, monitoring and management of the company's collections, disbursements and account balances; (c) the gathering and management of information to use available funds effectively and identify risk.

\footnotetext{
* Corresponding author.

E-mail address: somnath211@gmail.com (S. Das) 
In the present study we discussed another very important parameter of cash management i.e. Cash Conversion Cycle. The term Cash Conversion Cycle can be considered a length of time between purchase of raw-materials and collection of cash from debtors (Padachi, 2006, p. 49). In liquidity management Cash Conversion Cycle is an important parameter for measuring its efficiency (Jordon, 2003, p. 643). Cash Conversion Cycle of a company indicates the efficiency of managing working capital (Keown et al., 2003; Bodie \& Merton, 2000). Such measure can be used in benchmarking competitors or comparing companies. Cash Conversion Cycle is constructed by deducting the payable deferral period from the addition of inventory conversion period and receivable collection period (Bodie \& Merton, 2000, p. 89).

The CCC of a manufacturing organization may not be the same as the retail or wholesale organization even if for a service organization (Hutchison et al., 2007, p. 42). Cash Conversion Cycle of the organization is related with several factors like internal resources cost of external financing, conditions in the capital market and the bargaining power of debtors and creditors (Jose et al., 1996). Cash holding is one of the most important financial decisions that the manager of the concern organization, has to make in the organization. Some organization use to hold more cash and some organization hold less cash. But, how much to hold is the question. For this different policies are framed.

Modigliani Miller also opined for holding less amount of cash. Cash holding need good cash planning (Keynes, 1936). Prediction of cash is a process of estimating the probable sources and application of cash over a fixed future period (Dittmar \& Mahrt-Smith, 2007). It is a process through which first of all overall financial status of a company is identified and then determines probable financial needs with the help of budget (Jensen, 1986). For example, Kalcheva and Lins (2007), find that companies hold on an average of their total assets in cash or cash equivalents, Ferreira and Vilela (2004) find an average cash ratio of $15 \%$ and Guney et al. (2003) observe that the average cash ratio of the company is $14 \%$. Generally, fundamental accounting techniques for cash planning are (1) Proforma Balance Sheet, (2) Break-Even Analysis, (3) Cash forecast and (4) Cash Budget. Cash Budget can be prepared in two ways. They are (1) Receipts and Disbursement Method and (2) Adjusted Income Method. Appropriate cash holding is result of good cash planning.

A good cash management system ought to maintain an organizational framework which controls the cash flow. Such frame work identifies who is responsible for particular function viz. collecting cash, payment authorization, making payments, bank accounts and funds transfer between accounts, arranging overdraft facilities and loans, investing cash surpluses and foreign currency transaction. Another important topic of cash management is cash cycle. In business it is observed that cash received from selling of goods should exceed the cash paid for preparing such goods. In business organization cash payments are made in the expectation of receiving higher amount in future. A certain part of the cash receipts are utilized to prepare more goods or to provide more services for sale. Therefore, such activities generate the business cycle of purchasing and selling and paying for purchases and receiving from sales. Such concept gives birth of cash cycle. In organization cash cycle is related with the trading cycle. Trading cycle begins with the purchase of stock for resale and closed with sale of the stock. The cash cycle starts with payment of stock and closed with receipts of cash from customer for sale.

Both the trading cycle and cash flow cycle are measured by time. Earlier it is discussed that the trading cycle starts with purchasing of raw materials and ends of selling the goods. So, the trading cycle time would be the time from purchasing of raw materials to sale of finished goods whereas cash flow cycle time would be the time from first cash expenditures receipts of payments from sales. A credit availability can solves both of these problems. When the 'real economy' falls into recession, businesses face the additional risk of customers running into financial difficulty and becoming unable to pay invoices - which insists the organization to use non-operational sources such as bank loans, can push a company over the edge. Use of credit is a complex phenomenon. But, common people or even like us have wrong conception or negative idea about uses and application of credit. 'Buy now-pay later' or 
promise to pay in future for immediate goods are existed in the earlier agricultural societies. Giving credit means you are taking risk. Credit analysis is actually the risk analysis (Das, S. 2014, p.37). The credit analyst must consider the nature and type of the business as well as the applicant in his personal judgment.

\section{Review of Literature}

San Jose et al. (2008) conducted a study on approximately 501 Spanish firms with more than 10 employees and using confirmatory factor analysis observed that cash management was a culture that forms part of the strategy of the firms and dependent more on managers themselves than the characteristics of companies. Farris et al. (2011) made a study on cash to cash metric. For this they initially taken 21608 companies but latter such firms reduced to 5884 firms. This study presented an overview of cash to cash and its calculation, comparisons between product and service industries etc. The study also revealed that cash-to-cash knowledge of managers helped the service industries to improve their liquidity position and overall value. Deloof and Jegers (1996) undertook a study on working capital management. His study was based on cash conversion cycle. In his study he used different measures relating to the time lag between expenditure for the purchase of raw materials and collection of sales of finished goods. He argued that the longer the time lag, the larger the investment in working capital.

Kim et al. (1998) made a study on corporate liquidity in 1998. They used the logarithmic growth rate in the index of leading economic indicators as a proxy for the extent of profitable investment opportunities. They found that a firm's cash holdings increase with the level of investment opportunities and uncertainty in future cash flows. Similar type of study was conducted by Opler et al. (1999) and they also found the same results. Baskin and Miranti Jr (1999) in his study of Corporate Liquidity in Games of Monopoly Power in 1987 argued that firms with abundant investment opportunities also had an incentive to hold more cash to maintain their competitive positions. He also showed that holding excess cash might deter competition in a firm's product markets. Bathory (1987) in his book 'The Analysis of Credit' developed ratio based models of credit analysis. He opined that the greater the quality and quantity of data at the analyst's disposal, the better the credit opinion. For credit analysis he also suggested eight different ratios. These ratios are profitability, capital adequacy, liquidity, comfort margin, debt capacity, and priority debt service ability. He developed the model in such a way that the accuracy and relevance of the model's findings are directly proportional to the age and quality of the historical data. He argued that the model is also intended as a general diagnostic tool and it can be used by any commercial or industrial sector with the exception of banks, insurance companies or finance sectors. Basu (2011) made a study on eight cement companies using the Bathory's risk description model. The model is developed using four years data. In this study data have been collected from secondary sources i.e. The Stock Exchange official Directory of Bombay Stock Exchange and Capitaline data base. In this study the main focus is given to the liquidity, profitability and capital adequacy. The model also showed that these three ratios influenced the score of individual companies. He also showed that where these factors are good they obtained high score. Das (2014) made a study on IT sector. In this study he selected five companies from IT sector. In this study Bathory's Risk Description Model has been used to measure Credit Scores. For analysis data has been collected from Capitaline Corporate Database of Capital Market Publishers (I) Ltd. Mumbai. He pointed out that the companies having higher credit score increases their profitability.

\section{Objectives of the Study}

The presents study is prepared to make an in-depth analysis of the selected companies of Retail sector in respect of their Cash Conversion Cycle, Cash Holding and Credit Score during the period of 20022011. Cash conversion cycle is one of the dynamic measures of liquidity of the organization. Holding sufficient cash enables the organization to take the risk of borrowed capital, enlarge their assets position 
and investment to some profitable projects. Holding cash is an indicator of sound liquidity. It helps the organization in meeting their contractual obligation when they are due. Credit score is also one of the popular measures of liquidity and credit evaluation which helps the company to get more credit so that receivables are converted into cash in a minimum period of time, the company maintained the liquidity position property and maintained the growth opportunity. For determining credit analysis we always have to consider the nature and type of business as well as the judgment of the manager.

More specifically the objectives of our study as a whole are as under,

1. To design an effective Cash Management policy for smooth cash procurement and disbursement without endangering the operating capability and productivity of the firm.

2. To ensure adequate cash balance for payment of expenditures when they are due and at the same time maximizes the return on idle cash.

3. To determine the exact working cash balance in conformity with the nature of the firm and how the temporarily unused fund be invested in interest earning assets.

4. To make a comparative analysis of the Liquidity position of selected companies from five different sectors in India during the period covered in the study, i.e. 2002 to 2011.

5. To find out the Cash Conversion Cycle with help of RCP, ICP and PDP of the Selected Companies through the technique of ratio analysis and other statistical tools.

6. To set policies for reducing the cash conversion cycle as much as possible without affecting its operation process so that it leads to increase the profits of the firm.

7. To measure the Cash Flow from Operating activity, Investing activity and Financing activity and net increase / decrease in cash flow and try to establish the relationship between these activities with Cash Conversion Cycle and Cash Holding.

8. To measure the Credit Score (CS) and try to establish a relationship among Cash Conversion Cycle, Cash Holding and Creditworthiness.

9. Finally, to examine whether there is any relation among CCC, Cash Holding and Credit Score.

\section{Research Methodology used in this study}

Five companies from Retail Sector have been selected in this study. The data of the selected companies for the period 2002 to 2011 used in this study have been taken from the secondary sources i.e. Capitaline Corporate Database of Capital Market Publishers (I) Ltd. Mumbai. For the purpose of our study different companies from Retail sector are selected following the purposive sampling procedure.

Cash Conversion Cycle (CCC): Receivable conversion period, inventory conversion period and payment of deferral period are used to measure the cash conversion cycle. Shorter cash conversion cycle means better liquidity position of the organization. Here, we established the relationship between $\mathrm{CCC}$ and debtors more than six months, $\mathrm{CCC}$ and $\mathrm{CR}, \mathrm{CCC}$ and inventory turnover ratio, $\mathrm{CCC}$ and debtors turnover ratio and $\mathrm{CCC}$ and creditors turnover ratio. Debtors more than six months mean debtors from whom money is collected after six months. It is riskier to the organization and also blocks cash for long periods and reduces the liquidity position. Liquidity of the organization has been represented by the current ratio which is obtained by dividing the current assets to current liabilities. Efficiency of the inventory management has been measured by inventory turnover ratio (ITR) which is the ratio between cost of goods sold and average stock. Debtors' turnover ratio (DTR) is the ratio of 
credit sales to average receivables. Organization's ability to avail credit facility from suppliers has been measured by creditors' turnover ratio (CTR) which is the ratio of credit purchase to average payables.

Profitability, size of the organization and cumulative profitability can influence the cash conversion cycle of the organization. In this study profitability has been measured by return on net worth (RONW), size of the organization has been represented through the amount equal to the log value of total assets. Shareholders fund has been selected in this study as cumulative profitability which consists of equity share capital and reserve surpluses. The log value of shareholders' fund represents the cumulative profitability.

Average Cash Holding: Opening balance and closing balance of cash are used to determine the average cash balance of each year and again such cash balances are used to get the average cash holding. Large cash holding is preferable for better liquidity of the organization. In this study companies are ranked on the basis of average cash holding and consistency of cash holding sector wise and then ranking has been done as whole taking all twenty five companies considering the average cash holding and coefficients of variation (consistency) of average cash holding. In this study we examined the relationship between average cash holding and DFL, average cash holding and Investment and average cash holding and profitability (RONW). Degree of financial leverage (DFL) is computed with the help of the following formula,

\section{DFL $=$ Operating Profit $(E B I T) /($ Operating Profit - Interest $)$}

Financial leverage arises due to use of fixed charges bearing capital in the capital structure like debt capital. Higher debt capital means higher financial leverage. DFL measures the financial risk of the business. DFL affect the cash holding of the organization. More external borrowing means more cash holding. It can also be said that external borrowing replaces cash holding. Size of the organization has been represented through the amount equal to the log value of total assets. Size of the organization can affect the corporate cash holding. Generally, small firms hold more cash not only for higher costs of use of external funds but also for borrowing constraints. But large organization means too many expenses and for that purpose need large cash holding. Investment of the organization has been represented through the figure equal to the log value of total amount of Investment. Organization which have numerous investment opportunities but uncertain internal cash flow hold more cash otherwise borrowing external funds for profitable investment opportunity is costly. In this study profitability has been measured by the return on net worth (RONW). General principle is that higher the liquidity lowers the profitability. Holding more cash increases the short-term debt paying capacity of the organization, but decreases the profitability by not using the excess or unused fund in some other profitable projects.

Credit Score: To develop a credit evaluation model from the financial statement of the selected companies, we used Bathory's - 'risk description model' with small changes. In actual model the main influencing factors are accumulated profitability and inventory but for our purpose we use the cash flow instead of Inventory. Eight different ratios are calculated from the financial statement as stated above. In determination of ratios, emphasis has been given on the firms' liquidity, profitability and capital adequacy. For the purpose of our study five companies from Retail sector has been selected, as stated earlier, with the help of purposive sampling procedure. The model is prepared on the basis of ten years data; it will be more predictive and reveals the appropriate creditworthiness of the companies. For analyzing the date statistical tools like arithmetic mean, percentage etc. and statistical technique like Pearson's simple correlation analysis and statistical test like ' $t$ ' test have been applied at appropriate places.

\section{Risk Description Model}

1. Net Profit / Capital Employed = Profitability (Annual)

2. Net Tangible assets (Shareholders Fund) $/$ Total Liabilities $($ Long term + Short term debt $)=$ Profitability (Cumulative) 
3. Net Profit / Current Liabilities $=$ Liquidity

4. Normalized working capital / Credit Exposure = Capital Adequacy.

5. Equity / Current Liability + Credit exposure $=$ Capital Adequacy

6. Net Assets / Credit exposure $=$ Comfort Margin

7. Total assets / Total liability + Credit exposure $=$ Debt Capacity

8. Net Profit + Depreciation/ Current Debt $=$ Priority debt service ability.

In our model eight ratios are taken into consideration by giving equal weight to them.

The resulting formula would be denoted as -

$$
\begin{aligned}
& \mathrm{CS}=\mathrm{L} \times \sum \mathrm{xi} \\
& \mathrm{CS}=\text { Credit Scores } \\
& \mathrm{Xi}=\text { Variables }(\mathrm{i}=1 \text { to } 8) \\
& \mathrm{L}=\text { Constant Multiplier }=100 / 800=0.125
\end{aligned}
$$

The developed model is thus $=0.125 \times \sum \mathrm{xi}$

Risk Description Model

$$
\begin{aligned}
& \text { Here, } \\
& \text { NWC }=\text { Normalized Working Capital } \\
& \text { E }=\text { Net Tangible Assets } \\
& \text { CL = Current Liabilities } \\
& \text { TL }=\text { Total Liabilities } \\
& \text { CR. EXPOSU = Credit Exposure }(0.25 \% \text { of CA }) \\
& \text { CD = Current Debt } \\
& \text { D = Depreciation } \\
& \text { NP = Net Profit } \\
& \text { NA = Net Assets } \\
& \text { CE }=\text { Capital Employed. }
\end{aligned}
$$

For analyzing the data statistical tools like arithmetic mean, standard deviation coefficient of variation etc. and statistical techniques like Pearson's simple correlation analysis and multiple regression analysis and statistical test like ' $t$ ' test have been applied at appropriate places.

\section{Findings of the Study}

From Table 1 it has been observed that in case of Bata India Ltd. (Bata) the CCC is highest in the year 2004 (118.56 days) and smallest in the year 2011 (61.352 days). On an average it is 98.5 days. A mixed trend in CCC is observed during the study period. The liquidity position of the company is not at all satisfactory.

\section{Table 1}

Analysis of cash conversion cycle of selected companies of retail sector

\begin{tabular}{cllllllllllll}
\hline Industry & Companies & 2002 & 2003 & 2004 & 2005 & 2006 & 2007 & 2008 & 2009 & 2010 & 2011 & AVG \\
\hline \multirow{2}{*}{ Retail } & BATA & 105.16 & 114.89 & 118.56 & 105.69 & 109.5 & 107.71 & 96.44 & 87.92 & 78.05 & 61.52 & 98.5 \\
& SIYARAM & 140.67 & 145.33 & 138.98 & 123.21 & 100.71 & 101.6 & 110.93 & 103.90 & 70.38 & 69 & 110 \\
& GINI & 70.05 & 37.78 & 34.78 & 43.17 & 37.26 & 68.60 & 76.98 & 61.41 & 48.81 & 57.68 & 53.7 \\
& RAYMOND & 163.79 & 176.42 & 163.43 & 138.67 & 118.73 & 120.41 & 116.75 & 109.53 & 114.95 & 103.99 & 133 \\
& TITAN & 127.15 & 105.37 & 79.15 & 60.26 & 49.32 & 52.81 & 57.03 & 56.94 & 49.53 & 27.52 & 66.5 \\
\hline
\end{tabular}

Source: Compiled and computed from 'Capitaline Corporate Database' of Capital Market Publishers (I) Ltd., Mumbai.

In case of Siyaram Silk Mills (Siyaram), the CCC is highest in the year 2003(145.33 days) and lowest in the year 2011 (69 days). On an average it is 110 days. It follows a mixed trend of CCC during the study period. During the first half of the study period the CCC of the company is very high whereas 
the company improved its liquidity condition in the second half. Gini Fabrics follows a moderate CCC during the study period. Table 1 shows that the CCC of Gini Fabrics is highest in the year 2008 (76.98 days) and lowest in the year 2004 (34.78 days). On an average it is 53.7 days. It followed a mixed trend during the study period. The liquidity position of the company is moderate. From Table 1 it has been found that the CCC of Raymond is highest in the year 2003 (176.42 days) and smallest in the year 2011. On an average it is 133 days. The CCC trend is fluctuated during the study period. The company's liquidity position is not at all satisfactory throughout the study period. It may be due to lower debtors and inventory turnover. Table 1 shows that the CCC of Titan Industries Ltd. (Titan) is highest in 2002 (127.15 days) and lowest in 2011 (27.52 days). On an average it is 66.5 days. A mixed trend in CCC is noticed during the study period but it decreases in the last part of the study period. The Titan Ltd followed a moderate liquidity position throughout the study period. Therefore, among the five retail companies the average CCC of Gini Fabrics is lowest. It signifies that the short term liquidity position of Gini Fabrics is good.

\section{Table 2}

Ranking on the basis of average and consistency of cash conversion cycle of the selected companies of retail sector

\begin{tabular}{|c|c|c|c|c|c|c|c|c|}
\hline Industry & Companies & AVG. & SD & $\begin{array}{c}\text { RANK of } \\
\text { AVG. }\end{array}$ & $\begin{array}{c}\text { COEFFICIENT } \\
\text { of } \\
\text { VARIATION } \\
\end{array}$ & $\begin{array}{c}\begin{array}{c}\text { RANK } \\
\text { of } \\
\text { COEFFICIENT }\end{array} \\
\end{array}$ & $\begin{array}{l}\text { TOTAL } \\
\text { RANK }\end{array}$ & $\begin{array}{l}\text { OVER ALL } \\
\text { RANK }\end{array}$ \\
\hline \multirow[t]{5}{*}{ Retail } & BATA & 98.5 & 17.8724 & 3 & 18.136 & 1 & 4 & 1 \\
\hline & SIYARAM & 110 & 27.1761 & 4 & 24.599 & 3 & 7 & 3 \\
\hline & GINI & 53.7 & 15.3588 & 1 & 28.627 & 4 & 5 & 2 \\
\hline & RAYMOND & 133 & 26.1083 & 5 & 19.68 & 2 & 7 & 3 \\
\hline & TITAN & 66.5 & 29.5509 & 2 & 44.432 & 5 & 7 & 3 \\
\hline
\end{tabular}

In Table 2, the values of average Cash Conversion Cycle (CCC) of the companies under study have been ascertained by applying arithmetic mean and consistency of $\mathrm{CCC}$ have also been measured by using the coefficient of variation $(\mathrm{CV})$ of their cash conversion cycle. The industry wise ranks have been assigned to the selected companies both in respect of average and consistency. Among the companies of Indian Retail sector selected in this study the average CCC of Gini Fabrics is the lowest, followed by Titan, Bata, Siyaram and Raymond respectively. The table also reveals that in respect of consistency of designing CCC, Bata captured the top position and followed by Raymond, Siyaram, Gini Fabrics and Titan. Considering both average and consistency aspects together Bata occupied the first position whereas Gini Fabrics is in second place and rest three companies i.e. Siyaram, Raymond and Titan are in same rank. Coefficient of Correlation is the measurement of degree of association between two variables. A positive value of ' $r$ ' indicated high values of one variable are generally associated with the high values of other variables and low values with low values. In Table 3 an effort has been made to measure the degree of relationship between Cash Conversion Cycle (CCC) and each of the factors related with CCC such as inventory turnover ratio (ITR), current ratio (CR), debtors turnover ratio (DTR), debtors more than six months (Debt $>6$ Months) and creditors turnover ratio(CTR). To test the significance of such coefficient, ' $t$ ' test has been applied.

Table 3

Karl Pearson's Simple Correlation Analysis between CCC and ITR, CR, DTR, Debt $>6$ Months and CTR of the Selected

\begin{tabular}{|c|c|c|c|c|c|c|c|c|c|c|c|}
\hline \multirow[t]{2}{*}{ Industry } & \multirow[t]{2}{*}{ COMPANY } & \multicolumn{2}{|c|}{ CCC \& ITR } & \multicolumn{2}{|c|}{ CCC \& CR } & \multicolumn{2}{|c|}{ CCC \& DTR } & \multicolumn{2}{|c|}{$\begin{array}{c}\text { CCC \& DEBT }>6 \\
\text { MONTHS }\end{array}$} & \multicolumn{2}{|c|}{ CCC \& CTR } \\
\hline & & (r) & $\begin{array}{c}\text { 't' } \\
\text { Value }\end{array}$ & (r) & $\begin{array}{c}\text { 't' } \\
\text { Value }\end{array}$ & (r) & $\begin{array}{c}\text { 't' } \\
\text { Value }\end{array}$ & (r) & $\begin{array}{c}\text { 't' } \\
\text { Value }\end{array}$ & (r) & 't' Value \\
\hline \multirow{5}{*}{ Retail } & BATA & $0.859 * *$ & 4.746 & 0.100 & 0.284 & $0.778 * *$ & 3.503 & $-0.711^{*}$ & -2.86 & 0.040 & 0.1132 \\
\hline & SIYARAM & $0.979 * *$ & 13.58 & $-0.673^{*}$ & -2.57 & $0.965 * *$ & 10.41 & $-0.816^{* *}$ & -3.99 & -0.623 & -2.253 \\
\hline & GINI & $0.746^{*}$ & 3.168 & -0.357 & -1.08 & 0.531 & 1.772 & -0.007 & -0.02 & 0.549 & 1.8578 \\
\hline & RAYMOND & $0.853 * *$ & 4.623 & -0.047 & -0.13 & $0.759 *$ & 3.297 & $-0.733 *$ & -3.05 & 0.089 & 0.2527 \\
\hline & TITAN & -0.582 & -2.02 & 0.134 & 0.382 & $0.866^{* *}$ & 4.898 & -0.204 & -0.59 & $-0.807 * *$ & -3.865 \\
\hline
\end{tabular}

Note: Figures in the parentheses indicate ' $\mathrm{t}$ ' values. $\quad *$ Correlation is significant at the $5 \%$ level (2tailed). $* *$ Correlation is significant at the $1 \%$ level (2tailed).

Source: Compiled and computed from 'Capitaline Corporate Database' of Capital Market Publishers (I) Ltd., Mumbai. 
In retail sector the companies selected under study, Table 3 shows that the correlation coefficient between CCC and ITR of Bata, Siyaram, Gini Fabrics, Raymond are 0.859, 0.979, 0.746 and 0.853 respectively, which are statistically significant both at $5 \%$ and $1 \%$ level of significance. But the same in case of Titan it is (-) 0.582 , which is statistically insignificant. It implies that the sound inventory management in Bata, Siyaram, Gini Fabrics, Raymond helped to minimize CCC. But, in case Titan the inventory management system is not sound enough. Table 3 exhibits that in case of Retail sector the low positive correlation coefficient between CCC and CR is noticed in case of Bata and Titan, which are 0.100 and 0.134 respectively. It implies positive association between CCC and CR in these companies. On the other hand, the correlation coefficients between CCC and CR in Siyaram, Gini Fabrics and Raymond are (-) 0.673 , (-) 0.357 and (-) 0.047 respectively. Out of which the same in case of Siyaram is statistically significant at $5 \%$ level. It implies in efficient liquidity management.

Table 3 shows that in case of Retail sector the correlation coefficients between CCC and DTR are positive in all the companies selected under study. The correlation coefficients between CCC and DTR in Bata, Siyaram, Gini Fabrics, Raymond and Titan are 0.778, 0.965, 0.531, 0.759 and 0.866 respectively. Out of which the same in case of Bata, Siyaram, Raymond and Titan are statistically significant at 5\% level of significance. It indicates the positive association between CCC and DTR in these five companies. Hence the sound debtors management of all the companies of retail sector selected under the study helped to minimizes the CCC. It has been found from Table 3 that in Retail sector the correlation coefficient between CCC and debtors more than six months of all the companies are negative. The same in case of Bata, Siyaram, Gini Fabrics, Raymond and Titan are (-) 0.711, (-) 0.816, (-) 0.007, (-) 0.733 and (-) 0.204 respectively. Out of which the same in case of Bata, Siyaram and Raymond is statistically significant at $5 \%$ level of significance. The correlation coefficient of CCC and debtors more than six months is also statistically significant at $1 \%$ level. It implies the negative association between $\mathrm{CCC}$ and debtors more than six month of all the companies in retail sector selected under this study. It is due to the sound debtors' management. More specifically quick debt collection policy helps the companies to shorten their cash conversion cycle. It helps to improve the liquidity position. It has been viewed from Table 3 that in case of Retail sector the correlation coefficient between CCC and CTR in Siyaram and Titan are (-) 0.623 and (-) 0.807. Out of which the correlation coefficient between CCC and CTR in Titan is statistically significant both at 5\% and $1 \%$ level of significance. It implies the high negative relationship between CCC and CTR. It indirectly helps the above mentioned companies to shorten their CCC. On the other hand, the correlation coefficient between CCC and CTR in Bata, Gini Fabrics and Raymond registered a positive relationship and they are 0.040, 0.549 and 0.089 respectively and which are not statistically significant. It indicates positive relationship between CCC and CTR among the companies which is not desirable at all.

\section{Table 4}

Analysis of Multiple Regression of CCC on RONW, Size of Org. and shareholders' Fund of the Selected Companies of Retail Sector.

Regression Equation is CCC $=\mathrm{a}_{0}+\mathrm{a}_{1} \mathrm{RONW}+\mathrm{a}_{2}$ Size of Org. $+\mathrm{a}_{3}$ Shareholders' Fund

\begin{tabular}{|c|c|c|c|c|c|c|}
\hline \multirow[t]{2}{*}{ INDUSTRY } & \multirow[t]{2}{*}{ COMPANY } & \multicolumn{3}{|c|}{ PARTIAL REGRESSION COEFFICIENT } & \multirow{2}{*}{\multicolumn{2}{|c|}{ CONSTANT }} \\
\hline & & RONW & $\begin{array}{c}\text { SIZE OF THE } \\
\text { ORGANIZATION }\end{array}$ & $\begin{array}{c}\text { SHAREHOLDERS' } \\
\text { FUND }\end{array}$ & & \\
\hline \multirow{5}{*}{ 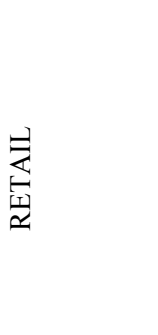 } & BATA & $\begin{array}{c}0.045 \\
(4.001)^{* * *}\end{array}$ & $\begin{array}{l}10.554 \\
(1.559)\end{array}$ & $\begin{array}{c}-1.443 \\
(-0.383)\end{array}$ & $\begin{array}{l}-19.799 \\
(-2.065)\end{array}$ & 0.836 \\
\hline & SIYARAM & $\begin{array}{c}0.032 \\
(0.966)\end{array}$ & $\begin{array}{l}-3.184 \\
(-1.156)\end{array}$ & $\begin{array}{c}9.328 \\
(2.131)^{*}\end{array}$ & $\begin{array}{l}-8.607 \\
(-2.806)\end{array}$ & 0.955 \\
\hline & GINI & $\begin{array}{c}-0.032 \\
(-0.340)\end{array}$ & $\begin{array}{l}-34.482 \\
(-1.802)\end{array}$ & $\begin{array}{c}28.635 \\
(1.931)^{*}\end{array}$ & $\begin{array}{l}15.361 \\
(1.703)\end{array}$ & 0.550 \\
\hline & RAYMOND & $\begin{array}{c}0.023 \\
(2.372)^{* *}\end{array}$ & $\begin{array}{c}6.088 \\
(9.057)^{* * *}\end{array}$ & $\begin{array}{l}-1.004 \\
(-1.046)\end{array}$ & $\begin{array}{l}-14.238 \\
(-6.594)\end{array}$ & 0.961 \\
\hline & TITAN & $\begin{array}{c}0.162 \\
(4.644)^{* * *}\end{array}$ & $\begin{array}{c}27.892 \\
(3.192)^{* *}\end{array}$ & $\begin{array}{l}-5.195 \\
(-1.455)\end{array}$ & $\begin{array}{l}-64.630 \\
(-3.720)\end{array}$ & 0.924 \\
\hline
\end{tabular}


In Table 4 an attempt has been made to assess the influence profitability, size of the organization and cumulative profitability on Cash Conversion Cycle. In this study, return on net-worth (RONW) has been taken as the measure of owners' profitability, log value of total assets has been taken as the measure of size of the organization and shareholder's fund has been taken as the measure of cumulative profitability. The linear regression equation has been fitted in this study is $C C C=b_{0}+b_{1} R O N W+b_{2}$ Size of Org. $+b_{3}$ Shareholders' fund, where $b_{0}$ is the value of intercept term (constant ) and $b_{1}, b_{2}$ and $b_{3}$ are the slopes of the line i.e. the regression coefficient of CCC on RONW, size of org. and Shareholders' fund. This regression equation has been tested by ' $t$ ' test. In case of Retail sector, the Table 4 shows that for one unit increase in RONW the CCC of Bata is increased by only 0.045 units but it is statistically significant at $1 \%$ level. From Table 4 it is clear that for one unit increase in size of the organization the CCC of Bata increased by 10.55 units which is statistically in significant. On the other hand, Table 4 shows that for one unit increase in cumulative profitability, the CCC of Bata decreased by 1.44 units which is also statistically insignificant. It implies that both profitability and size of the organization positively influenced the $\mathrm{CCC}$ of Bata while cumulative profitability negatively influenced the CCC of the company. The coefficient of determination $\left(\mathrm{R}^{2}\right)$ makes it clear that $83.6 \%$ of the variation of the company's CCC is accounted for by the variation in RONW, Size of Org and Shareholders' fund.

It is found from Table 4 that for one unit increases in RONW the CCC of Siyaram gone up only 0.032 units which is statistically insignificant. The Table 4 also shows that for one unit increase in size of the organization the CCC of Siyaram decreased by 3.184 units which is statistically insignificant. Table 4 shows that for one unit increase in cumulative profitability the CCC of the company stepped up by 9.328 units which is statistically significant at $5 \%$ level. It implies that profitability and cumulative profitability positively influenced the CCC of the company while size of the organization negatively influenced the CCC of the company. The coefficient of determination $\left(\mathrm{R}^{2}\right)$ makes it clear that $95.5 \%$ of the variation of the company's CCC is accounted for by the variation in RONW, Size of Org and Shareholders' fund.

It has been observed from Table 4 that for one unit increases in RONW the CCC of the Gini Fabrics decreased by 0.032 units which is statistically insignificant. The table depicts that for one unit change in size of the organization the CCC of the company decreased by 34.482 units which is statistically insignificant. Table 4 also shows that for one unit increase in cumulative profitability, the CCC of Gini Fabrics increased by 28.635 units which is statistically significant at $5 \%$ level. It indicates that only cumulative profitability positively influenced the CCC of the company while RONW and size of the company negatively influenced the CCC of the company. The coefficient of determination $\left(\mathrm{R}^{2}\right)$ makes it clear that $55.0 \%$ of the variation of the company's CCC is accounted for by the variation in RONW, Size of Org and Shareholders' fund. It is found from Table 4 that for one unit increase in RONW and size of the organization the CCC of Raymond increased by 0.023 units and 6.088 units respectively and they are statistically significant at 5\% and 1\% level of significance. On the other hand Table 4 shows that for one unit increase in cumulative profitability the CCC of the company decreased by 1.004 units which is statistically insignificant at 5\% level. It indicates that both RONW and size of the organization influenced the CCC of the Raymond positively whereas the influence of cumulative profitability on CCC of the company is negative. The coefficient of determination $\left(\mathrm{R}^{2}\right)$ makes it clear that $96.1 \%$ of the variation of the company's CCC is accounted for by the variation in RONW, Size of Org and Shareholders' fund. It has been found from Table 4 that for one unit increase in RONW and size of the organization, the CCC of Titan go up by 0.162 unit and 27.892 units respectively, out of which previous one is statistically significant at $1 \%$ level and the later one is statistically significant at $5 \%$ level. On the other hand Table 4 shows that for one unit increase in cumulative profitability the CCC of the organization decreased by 5.195 units. It indicates that both RONW and size of the organization positively influenced the CCC of the company while cumulative profitability negatively influenced the CCC of the organization. The coefficient of determination $\left(\mathrm{R}^{2}\right)$ makes it clear that $92.4 \%$ of the variation of the company's CCC is accounted for by the variation in RONW, Size of Org and 
Shareholders' fund. Therefore, under Retail sector all the influencing factors such as RONW, size of the organization and cumulative profitability more or less, positively or negatively affect the CCC of each company selected under study. Out of which the effect of RONW in Bata, size of the organization in Raymond and Titan is significant than others.

\section{Cash Holding}

From Table 5 it is observed that the average Cash Holding (ACH) in Bata India Ltd. (Bata) is highest in the year 2006 (Rs.17.505 Crore) and lowest in the year 2004(Rs.3.23 Crore). On an average it is Rs.10.1Crore. The ACH of the company is fluctuated throughout the study period. In the year 2006 the average cash holding as percentage of total assets is highest which is $5.10 \%$. The company maintained low level of cash which also decreases the liquidity position of the company.

\section{Table 5}

Analysis of Average Cash Holding (Avg. Cash Holding as percentage of total assets) of Selected Companies of Retail sector

Rs. in crore (also in \% of total assets)

\begin{tabular}{|c|c|c|c|c|c|c|c|c|c|c|c|}
\hline \multirow{2}{*}{ COMPANIES } & \multicolumn{10}{|c|}{ Years } & \multirow{2}{*}{ AVG. } \\
\hline & 2002 & 2003 & 2004 & 2005 & 2006 & 2007 & 2008 & 2009 & 2010 & 2011 & \\
\hline BATA & $\begin{array}{c}3.85 \\
(1.62)\end{array}$ & $\begin{array}{c}3.52 \\
(0.95)\end{array}$ & $\begin{array}{c}3.23 \\
(0.95)\end{array}$ & $\begin{array}{c}8.95 \\
(2.89)\end{array}$ & $\begin{array}{l}17.51 \\
(5.10)\end{array}$ & $\begin{array}{c}9.62 \\
(3.53)\end{array}$ & $\begin{array}{l}13.01 \\
(4.28)\end{array}$ & $\begin{array}{l}11.31 \\
(3.36)\end{array}$ & $\begin{array}{l}13.12 \\
(3.65)\end{array}$ & $\begin{array}{c}16.55 \\
(4.020)\end{array}$ & $\begin{array}{c}10.1 \\
(2.98)\end{array}$ \\
\hline SIYARAM & $\begin{array}{c}0.85 \\
(0.38)\end{array}$ & $\begin{array}{c}1.17 \\
(0.54)\end{array}$ & $\begin{array}{c}1.64 \\
(0.75)\end{array}$ & $\begin{array}{c}1.36 \\
(0.58)\end{array}$ & $\begin{array}{c}0.92 \\
(0.37)\end{array}$ & $\begin{array}{c}1.23 \\
(0.37)\end{array}$ & $\begin{array}{c}1.26 \\
(1.30)\end{array}$ & $\begin{array}{c}1.63 \\
(0.43)\end{array}$ & $\begin{array}{c}2.54 \\
(0.70)\end{array}$ & $\begin{array}{c}2.91 \\
(0.57)\end{array}$ & $\begin{array}{l}1.55 \\
(0.5)\end{array}$ \\
\hline GINI & $\begin{array}{c}0.14 \\
(1.04)\end{array}$ & $\begin{array}{c}0.44 \\
(3.94)\end{array}$ & $\begin{array}{c}0.88 \\
(7.94)\end{array}$ & $\begin{array}{c}0.78 \\
(7.42)\end{array}$ & $\begin{array}{c}0.4 \\
(3.83)\end{array}$ & $\begin{array}{c}1.3 \\
(11.05)\end{array}$ & $\begin{array}{c}1.23 \\
(9.36)\end{array}$ & $\begin{array}{c}0.14 \\
(0.91)\end{array}$ & $\begin{array}{c}0.09 \\
(0.48)\end{array}$ & $\begin{array}{c}0.10 \\
(0.42)\end{array}$ & $\begin{array}{c}0.55 \\
(4.64)\end{array}$ \\
\hline RAYMOND & $\begin{array}{l}21.70 \\
(1.52)\end{array}$ & $\begin{array}{l}24.68 \\
(1.72)\end{array}$ & $\begin{array}{l}20.85 \\
(1.37)\end{array}$ & $\begin{array}{l}20.01 \\
(1.19)\end{array}$ & $\begin{array}{l}19.14 \\
(0.97)\end{array}$ & $\begin{array}{l}25.32 \\
(1.18)\end{array}$ & $\begin{array}{l}23.72 \\
(1.03)\end{array}$ & $\begin{array}{l}34.31 \\
(1.38)\end{array}$ & $\begin{array}{l}36.68 \\
(1.51)\end{array}$ & $\begin{array}{l}29.16 \\
(1.26)\end{array}$ & $\begin{array}{c}25.6 \\
(1.31)\end{array}$ \\
\hline TITAN & $\begin{array}{r}22.43 \\
(3.69) \\
\end{array}$ & $\begin{array}{l}20.63 \\
(3.28) \\
\end{array}$ & $\begin{array}{r}25.87 \\
(4.52) \\
\end{array}$ & $\begin{array}{c}35.69 \\
(7.2) \\
\end{array}$ & $\begin{array}{r}41.09 \\
(8.2) \\
\end{array}$ & $\begin{array}{l}44.39 \\
(7.72) \\
\end{array}$ & $\begin{array}{r}51.25 \\
(7.38) \\
\end{array}$ & $\begin{array}{r}53.33 \\
(7.33) \\
\end{array}$ & $\begin{array}{c}120.71 \\
(15.14) \\
\end{array}$ & $\begin{array}{l}640.81 \\
(58.62) \\
\end{array}$ & $\begin{array}{c}106 \\
(12.3) \\
\end{array}$ \\
\hline
\end{tabular}

Source: Compiled and computed from 'Capitaline Corporate Database' of Capital Market Publishers (I) Ltd., Mumbai

It has been revealed from Table 5 that the ACH of Siyaram Silk Mills (Siyaram) is highest in the year 2011(Rs.2.905 Crore) and lowest in the year 2002(Rs.0.845 Crore). On an average it is Rs.1.55 Crore. The ACH of the company fluctuated in the first half of the study period whereas an increasing trend is noticed during the second half of the study period. The average cash holding as percentage of total assets is highest in the year 2004 which is $0.75 \%$. The company maintained very low level of cash in the entire study period. It indicates that the liquidity position of the company is very poor. In case of Gini Fabrics Table 5 depicts that the ACH of the company is highest in the year 2007 (Rs.1.295 Crore) and lowest in the year 2010(Rs.0.09 Crore). On an average it is Rs.0.55Crore. The ACH of the company has fluctuated throughout the study period. The table shows that Gini Fabrics maintained very low level of cash during the study period. From the point of view of average cash holding as percentage of total assets, highest percentage is noticed in the year 2007 (11.05\%). It implies that the liquidity position of the company from the point of view of ACH is very poor. It is revealed from Table 5 that the ACH of Raymond is highest in the year 2010 (Rs.36.68Crore) and lowest in the year 2006(Rs.19.14 Crore). On an average it is Rs.25.6 Crore. The ACH of the company fluctuated throughout the study period. In the year 2003 the average cash holding as percentage of total assets is highest which is only $1.72 \%$. The company maintained a standard cash level during the study period. It implies that the company followed a moderate liquidity position during the study period. From Table 5 it is observed that the ACH of Titan Industries Ltd. (Titan) is highest in the year 2011 (Rs.640.805 Crore) and lowest in the year 2003(Rs.20.63 Crore). On an average it is Rs.106 Crore. The company followed an increasing trend in ACH throughout the study period except in the year 2003. The average cash holding as compared to total assets is highest in the year 2011 which is $58.62 \%$. It implies that the company has improved its liquidity position from year after year. Therefore, in Retail sector, Titan holds higher level of cash as compared to other companies. In consequence with we can say that the liquidity condition of Titan is far better than other companies in respect of cash holding. 
Table 6

Ranking on the basis of average and consistency of average cash holding of the selected companies of retail sector

\begin{tabular}{|c|c|c|c|c|c|c|c|}
\hline Companies & $\begin{array}{l}\text { Avg. Cash as } \% \text { of } \\
\text { Total Assets }\end{array}$ & SD & $\begin{array}{l}\text { Rank of } \\
\text { Avg. }\end{array}$ & $\begin{array}{c}\text { Coefficients of } \\
\text { variation }\end{array}$ & $\begin{array}{c}\text { Rank of } \\
\text { Coefficients }\end{array}$ & Total Rank & $\begin{array}{c}\text { Over all } \\
\text { Rank }\end{array}$ \\
\hline BATA & 2.98 & 4.966 & 3 & 49.35 & 3 & 6 & 2 \\
\hline SIYARAM & 0.5 & 0.639 & 5 & 41.29 & 2 & 7 & 5 \\
\hline GINI & 4.64 & 0.444 & 2 & 81.17 & 4 & 6 & 2 \\
\hline RAYMOND & 1.31 & 5.715 & 4 & 22.36 & 1 & 5 & 1 \\
\hline TITAN & 12.3 & 180.5 & 1 & 170.9 & 5 & 6 & 2 \\
\hline
\end{tabular}

Source: Compiled and computed from ‘Capitaline Corporate Database' of Capital Market Publishers (I) Ltd., Mumbai.

From Table 6 it is clear that among the companies of Retail sector selected in this study, the Average Cash Holding as \% of Total Assets, Titan is the highest, followed by Gini Fabrics, Bata, Raymond and Siyaram respectively. The table also reveals that according to consistency of constructing ACH, Raymond captured the top most position and it followed by Siyaram, Bata, Gini Fabrics and Titan. Considering both average and consistency point of view Raymond occupied the first place and it followed by Bata, Gini Fabrics, Titan and Siyram. Coefficient of correlation is the measurement of degree of association between two variables. A positive value of ' $r$ ' indicated high values of one variable are generally associated with the high values of other variables and low values with low values. In Table 7 an effort has been made to measure the degree of relationship between $\mathrm{ACH}$ and each of the factors related with cash holding such as degree of financial risk (DFL), size of the organization, Investment of the organization and lastly profitability (RONW). To test the significance of such coefficient ' $t$ ' test has been applied.

\section{Table 7}

Karl Pearson's simple correlation analysis between AVG cash holding and DFL, Size of Org., Investment and RONW of the selected companies of retail sector

\begin{tabular}{|c|c|c|c|c|c|c|c|c|}
\hline \multirow[t]{2}{*}{ COMPANY } & \multicolumn{2}{|c|}{$\begin{array}{c}\text { AVG CASH HOLDING \& } \\
\text { DFL }\end{array}$} & \multicolumn{2}{|c|}{$\begin{array}{c}\text { AVG CASH HOLDING } \\
\& \\
\text { SIZE OF ORG. }\end{array}$} & \multicolumn{2}{|c|}{$\begin{array}{c}\text { AVG CASH HOLDING } \\
\& \\
\text { INVESTMENT }\end{array}$} & \multicolumn{2}{|c|}{$\begin{array}{c}\text { AVG CASH HOLDING \& } \\
\text { RONW }\end{array}$} \\
\hline & (r) & 't' Value & (r) & 't' Value & (r) & 't' Value & (r) & $\begin{array}{c}\text { 't' } \\
\text { Value }\end{array}$ \\
\hline BATA & -0.368 & -1.1 & -0.118 & -0.336 & 0.626 & 2.271 & $0.831 * *$ & 4.225 \\
\hline SIYARAM & -0.210 & -0.6 & $0.657^{*}$ & 2.4649 & $0.884 * *$ & 5.348 & $0.725^{*}$ & 2.977 \\
\hline GINI & 0.358 & 1.08 & $-0.740^{*}$ & -3.112 & $-0.749 *$ & -3.197 & $-0.736^{*}$ & -3.08 \\
\hline RAYMOND & -0.206 & -0.6 & $0.684^{*}$ & 2.6521 & 0.414 & 1.286 & -0.591 & -2.07 \\
\hline TITAN & $-0.679 *$ & -2.6 & $0.846 * *$ & 4.4879 & $-0.660 *$ & -2.485 & 0.568 & 1.952 \\
\hline
\end{tabular}

Table 7 shows that in Retail sector the correlation coefficient between ACH and DFL in Bata, Siyaram, Raymond and Titan are (-) $0.368,(-) 0.210$, (-) 0.206 and (-) 0.679 respectively. All the correlation coefficients are negative out of which the coefficient of Titan is statistically significant at $5 \%$ level. Only the correlation coefficient between ACH and DFL in Gini Fabrics is 0.358, positive. It implies that incase of Gini Fabrics it is positive. It has been depicted from Table 7 that in Retail sector, the correlation coefficient between $\mathrm{ACH}$ and Size of the organization in Bata, Siyaram, Gini Fabrics, Raymond and Titan are (-) $0.118,0.657,(-) 0.740,0.684$ and 0.846 respectively. Out of which the correlation coefficient between ACH and Size of the organization in Siyaram, Raymond and Titan are positive and are statistically significant either at $5 \%$ or $1 \%$ or both at $5 \%$ and $1 \%$ level of significance. It indicates that in Siyaram, Raymond and Titan the ACH and Size of the organization are positively related. On the other hand, the correlation coefficients between $\mathrm{ACH}$ and Size of the organization in Bata and Gini Fabrics, ACH is negatively associated with size of the organization. From Table 7 it is depicted that in Retail sector the correlation coefficient between $\mathrm{ACH}$ and Investment in Bata, Siyaram, Gini Fabrics, Raymond and Titan are 0.626, 0.884, (-) 0.749, 0.414 and (-) 0.660. Out of which the correlation coefficient between ACH and Investment in Bata, Siyaram and Raymond is positive and the coefficient of Siyaram is statistically significant both at $5 \%$ and $1 \%$ level of significance. It signifies that in Bata, Siyaram and Raymond the association between $\mathrm{ACH}$ and Investment is positive. On the other hand, the correlation coefficients between ACH and Investment in Gini Fabrics and Titan are 
negative and both are statistically significant at 5\% level. It implies that in Gini Fabrics and Titan, ACH is negatively related with Investment. At last in Retail sector table reveals that the correlation coefficient between ACH and RONW in Bata, Siyaram, GiniFabrics, Raymond and Titan are 0.831, 0.725, (-) 0.736, (-) 0.591 and 0.568 respectively. Out of which the coefficients in Bata, Siyaram and Titan are positive. The coefficients of Bata and Siyaram are also significant at $1 \%$ and $5 \%$ level of significance respectively. It implies that in Bata, Siyaram and Titan the strength of relationship between $\mathrm{ACH}$ and RONW in Gini Fabrics and Raymond are negative. Out of which the coefficient of Gini Fabrics is statistically significant at 5\% level. It implies that in Gini Fabrics and Raymond ACH is negatively associated with RONW. It follows the principle.

\section{Table 8}

Analysis of Multiple Regression of Avg. Cash Holding on DFL, Size of Org. and Investment of the Selected Companies of Retail Sector.

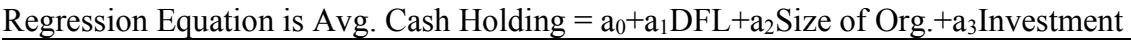

\begin{tabular}{|c|c|c|c|c|c|}
\hline \multirow{2}{*}{ COMPANIES } & \multicolumn{3}{|c|}{ PARTIAL REGRESSION COEFFICIENT } & \multirow{2}{*}{ CONSTANT } & \multirow{2}{*}{$\mathrm{R}^{2} \mathrm{ED}$} \\
\hline & DFL & $\begin{array}{c}\text { SIZE OF THE } \\
\text { ORGANISTION }\end{array}$ & INVESTMENT & & \\
\hline BATA & $\begin{array}{l}-0.031 \\
(-0.667)\end{array}$ & $\begin{array}{c}0.215 \\
(0.124)\end{array}$ & $\begin{array}{c}0.557 \\
(1.775)\end{array}$ & $\begin{array}{l}-0.096 \\
(-0.022)\end{array}$ & 0.434 \\
\hline SIYARAM & $\begin{array}{l}-0.156 \\
(-0.580)\end{array}$ & $\begin{array}{c}0.079 \\
(0.205)\end{array}$ & $\begin{array}{c}0.150 \\
(2.776)^{* *}\end{array}$ & $\begin{array}{c}0.208 \\
(0.232)\end{array}$ & 0.793 \\
\hline GINI & $\begin{array}{l}-0.416 \\
(-0.133)\end{array}$ & $\begin{array}{l}-1.780 \\
(-1.036)\end{array}$ & $\begin{array}{l}-0.350 \\
(-1.174)\end{array}$ & $\begin{array}{c}2.079 \\
(0.461)\end{array}$ & 0.636 \\
\hline RAYMOND & $\begin{array}{c}0.028 \\
(0.631)\end{array}$ & $\begin{array}{c}1.284 \\
(2.116)^{*}\end{array}$ & $\begin{array}{l}-0.763 \\
(-1.123)\end{array}$ & $\begin{array}{l}-0.642 \\
(-0.672)\end{array}$ & 0.560 \\
\hline TITAN & $\begin{array}{c}-0.272 \\
(-1.998)^{*}\end{array}$ & $\begin{array}{c}2.808 \\
(3.032)^{* *}\end{array}$ & $\begin{array}{l}-0.068 \\
(-0.199)\end{array}$ & $\begin{array}{l}-5.664 \\
(-1.947)\end{array}$ & 0.842 \\
\hline
\end{tabular}

In Table 8 an attempt has been made to assess the influence of DFL, Size of the organization and Investment on Average Cash Holding. In this study DFL has been taken as the measure of financial risk, log value of total assets has been taken as the measure of size of the organization and log value of total investment has been taken as the measure of Investment. The linear regression equation has been fitted in this study ACH $=b_{0}+b_{1} D F L+b_{2}$ Size of the org. $+b_{3}$ Investment, $b_{0}$ is the value of intercept term (constant) and $b_{1}, b_{2}$ and $b_{3}$ are the slopes of the line, i.e. the regression coefficient of $A C H$ on $\mathrm{DFL}$, Size of the organization and Investment. This regression equation has been tested by ' $t$ ' test. Now, in Retail sector, Table 8 exhibits that for one unit increase in DFL the ACH of Bata decreased by only 0.031 units which is insignificant. Table 8 is also revealed that for one unit increase in size of the organization the $\mathrm{ACH}$ of Bata increased by 0.215 units which is insignificant.

\section{Table 9}

Risk Description Model - Ratio Measurement(Bata)

\begin{tabular}{lcc}
\hline RATIOS & DESCRIPTION & AVG. SCORES \\
\hline X1 & NP/CE & 0.10162 \\
X2 & NTA/TL & 1.26403 \\
X3 & NP/CL & 0.16771 \\
X4 & NWC/CR.EXPOSU & 44.376 \\
X5 & E/CL+CR.EXPOSU & 1.53644 \\
X6 & NA/CR.EXPOSU & 276.247 \\
X7 & TA/TL+CR.EXPOSU & 2.52218 \\
X8 & NP+D/CD & 1.28619 \\
\hline TOTAL AVG SCORES & & 327.501 \\
CREDIT SCORES(CS) & & 40.9377 \\
\hline
\end{tabular}


Table 8 shows that for one unit increase in Investment the ACH of Bata increased by 0.557 units which is statistically not significant. It signifies that both the size of the organization and Investment is positively influenced the ACH of Bata whereas DFL has negative influence on ACH. The coefficient of determination $\left(\mathrm{R}^{2}\right)$ makes it clear that only $43.4 \%$ of the variation of the company's $\mathrm{ACH}$ is accounted for by the variation in DFL, Size of Org and Investment. It has been observed from Table 8 that for one unit increase in DFL the ACH of Siyaram goes down by 0.156 units, which is insignificant. Table 8 also portrays that for one unit increase in size of the organization the ACH of Siyaram goes up by 0.079 units which is insignificant. Table 8 also reveals that for one unit increase in Investment the $\mathrm{ACH}$ of Siyaram increased by 0.150 units which is statistically significant at $5 \%$ level.

Table 10

\begin{tabular}{lcc}
\multicolumn{2}{l}{ Risk description model - Ratio measurement(Siyaram) } & \\
\hline RATIOS & DESCRIPTION & AVG SCORES \\
\hline X1 & NP/CE & 0.0747 \\
X2 & NTA/TL & 2.73559 \\
X3 NP/CL & 0.58786 \\
X4 & NWC/CR.EXPOSU & 225.117 \\
X5 & E/CL+CR.EXPOSU & 3.43528 \\
X6 & NA/CR.EXPOSU & 241.626 \\
X7 & TA/TL+CR.EXPOSU & 7.34629 \\
X8 & NP+D/CD & 4.88841 \\
\hline TOTAL AVG SCORES & & 485.811 \\
CREDIT SCORES(CS) & 60.7264 \\
\hline
\end{tabular}

It implies that size of the organization and Investment influenced the ACH positively which is also significant whereas DFL, negatively influence the ACH of Siyaram. The coefficient of determination $\left(\mathrm{R}^{2}\right)$ makes it clear that only $79.3 \%$ of the variation of the company's $\mathrm{ACH}$ is accounted for by the variation in DFL, Size of Org and Investment. Table 10 exhibits that for one unit increase in all the factors like DFL, Size of the Organization and Investment the ACH of Gini Fabrics are go down by 0.416 units, 1.780 units and 0.350 units respectively and none of them is significant. It indicates that all the factors have negatively influence the ACH of Gini Fabrics. The coefficient of determination $\left(\mathrm{R}^{2}\right)$ makes it clear that only $63.6 \%$ of the variation of the company's ACH is accounted for by the variation in DFL, Size of Org and Investment. Now, Table 8 exhibits that for one unit increase in DFL and Size of the organization, the ACH of Raymond stepped up by 0.028 units and 1.284 units respectively, out of which last one is statistically significant at $10 \%$ level. The Table 8 also shows that for one unit increase in Investment the ACH of Raymond go down by 0.763 units which is insignificant. It indicates that DFL and Size of the organization in Raymond influenced the ACH positively whereas Investment influenced the ACH negatively. The coefficient of determination $\left(\mathrm{R}^{2}\right)$ makes it clear that only $56 \%$ of the variation of the company's ACH is accounted for by the variation in DFL, Size of Organization and Investment. Table 8 shows that for one unit increase in DFL and Investment, the ACH of Titan go down by 0.272 units and 0.068 units respectively and out of which, first one is statistically significant at $10 \%$ level. Table also reveals that for one unit increase in size of the organization, the ACH go up by 2.808 units, which is statistically significant at 5\% level. It implies that DFL and Investment influence the $\mathrm{ACH}$ in Titan negatively while Size of the organization positively influenced the ACH of Titan. The coefficient of determination $\left(\mathrm{R}^{2}\right)$ makes it clear that only $84.2 \%$ of the variation of the company's ACH is accounted for by the variation in DFL, Size of Organization and Investment. Therefore, it is clear that only in case of Gini Fabrics all the factors influenced the ACH negatively. In most of the cases Size of the organization influenced the ACH positively with high level of significance.

\section{Risk description Model}

The main purpose of calculating ratios is to judge the firm's liquidity, profitability and capital adequacy. From the 'risk description model', scores are calculated individually for each of the selected companies under study. Tables are prepared consisting of different ratios to calculate scores. The model clearly showed that how the liquidity, profitability and capital adequacy factors influenced the scores of individual companies. In case of all the companies from five different sectors, where all the factors are 
good, they obtained high score. Contrary, the companies where two factors are good but the impact of one or two bad factor / factors outweighed the influence of good factors. Now, in Retail sector Table 9 reveals that the average scores of ratio $\mathrm{x}_{1}, \mathrm{x}_{2}, \mathrm{x}_{3}, \mathrm{x}_{4}, \mathrm{x}_{5}, \mathrm{x}_{6}, \mathrm{x}_{7}$ and $\mathrm{x}_{8}$ in Bata India Ltd. (Bata) are $0.101,1.26,0.167,44.37,1.53,276.24,2.52$ and 1.28 . The highest score deserved by ratio $\mathrm{x}_{6}(276.24)$ and lowest score registered by ratio $\mathrm{x}_{1}(0.101)$. Total average score of Bata is 327.5. The credit score of Bata is 40.93. Table 10 shows that the average score of ratio $\mathrm{x}_{1}, \mathrm{x}_{2}, \mathrm{x}_{3}, \mathrm{x}_{4}, \mathrm{x}_{5}, \mathrm{x}_{6}, \mathrm{x}_{7}$ and $\mathrm{x}_{8}$ in Siyaram Silk Mills (Siyaram) are 0.074, 2.735, 0.58, 225.117, 3.435, 241.62, 7.34 and 4.88 respectively. Out of which ratio $\mathrm{x}_{6}$ is the highest which is 241.626 and ratio $\mathrm{x}_{1}$ is the lowest which is 0.074 . Total average score of Siyaram is 485.811 . The credit score of Siyaram is 60.726 . From Table 11 it is found that the average score of ratio $\mathrm{x}_{1}, \mathrm{x}_{2}, \mathrm{x}_{3}, \mathrm{x}_{4}, \mathrm{x}_{5}, \mathrm{x}_{6}, \mathrm{x}_{7}$ and $\mathrm{x}_{8}$ in Gini Fabrics are 0.110, 4.916, 0.540, 179.071, $5.929,659.039,6.179$ and 5.166 respectively. The highest score represented by ratio $\mathrm{x}_{6}$ which is 659.039 and lowest score represented by ratio $\mathrm{x}_{1}$ which is 0.110 . The total average score of Gini Fabrics is 860.954. The credit score of Gini Fabrics is 107.619.

Table 11

Risk Description Model - Ratio Measurement (Gini Fabrics)

\begin{tabular}{lcc}
\hline RATIOS & DESCRIPTION & AVG SCORES \\
\hline X1 & NP/CE & 0.11099 \\
X2 & NTA/TL & 4.91676 \\
X3 & NP/CL & 0.54067 \\
X4 & NWC/CR.EXPOSU & 179.071 \\
X5 & E/CL+CR.EXPOSU & 5.92911 \\
X6 & NA/CR.EXPOSU & 659.039 \\
X7 & TA/TL+CR.EXPOSU & 6.17993 \\
X8 & NP+D/CD & 5.16641 \\
\hline TOTAL AVG SCORES & & 860.954 \\
CREDIT SCORES(CS) & & 107.619 \\
\hline
\end{tabular}

Table 12

Risk Description Model- Ratio Measurement(Raymond)

\begin{tabular}{lcc}
\hline RATIOS & DESCRIPTION & AVG SCORES \\
\hline X1 & NP/CE & 0.05714 \\
X2 & NTA/TL & 3.46922 \\
X3 & NP/CL & 0.45976 \\
X4 & NWC/CR.EXPOSU & 166.565 \\
X5 & E/CL+CR.EXPOSU & 4.39973 \\
X6 & NA/CR.EXPOSU & 548.329 \\
X7 & TA/TL+CR.EXPOSU & 6.8527 \\
X8 & NP+D/CD & 0.74688 \\
\hline TOTAL AVG SCORES & & 730.879 \\
CREDIT SCORES(CS) & & 91.3599 \\
\hline
\end{tabular}

Table 12 exhibits that the average score of ratio $\mathrm{x}_{1}, \mathrm{x}_{2}, \mathrm{x}_{3}, \mathrm{x}_{4}, \mathrm{x}_{5}, \mathrm{x}_{6}, \mathrm{x}_{7}$ and $\mathrm{x}_{8}$ in Raymond are 0.057 , $3.469,0.459,166.565,4.399,548.32,6.852$ and 0.746 respectively. Out of which ratio $\mathrm{x}_{6}(548.329)$ is the highest and ratio $\mathrm{x}_{1}(0.057)$ is the lowest. The total average score is 730.879 . The credit score of Raymond is 91.35 .

Table - 13

Risk Description Model - Ratio Measurement(Titan)

\begin{tabular}{lcc}
\hline RATIOS & DESCRIPTION & AVG SCORES \\
\hline X1 & NP/CE & 0.20595 \\
X2 & NTA/TL & 0.70893 \\
X3 & NP/CL & 0.29252 \\
X4 & NWC/CR.EXPOSU & 72.2065 \\
X5 & E/CL+CR.EXPOSU & 0.77137 \\
X6 & NA/CR.EXPOSU & 134.306 \\
X7 & TA/TL+CR.EXPOSU & 2.84694 \\
X8 & NP+D/CD & 1.8691 \\
\hline TOTAL AVG SCORES & & 213.208 \\
CREDIT SCORES(CS) & & 26.6509 \\
\hline
\end{tabular}


Table 13 reveals that the average score of ratio $\mathrm{x}_{1}, \mathrm{x}_{2}, \mathrm{x}_{3}, \mathrm{x}_{4}, \mathrm{x}_{5}, \mathrm{x}_{6}, \mathrm{x}_{7}$ and $\mathrm{x}_{8}$ in Titan Industries Ltd. (Titan) are $0.205,0.708,0.292,72.20,0.771,134.306,2.84$, and 1.869 respectively. Out of which ratio $\mathrm{x}_{6}$ is the highest, which is 134.306 , and ratio $\mathrm{x}_{1}$ is the lowest, which is 0.205 . The total average score of Titan is 213.208. The credit score of Titan is 26.65 .

Therefore, in Retail sector Tables 9-13 reveal that the current profitability condition is the best in Titan Ltd. whereas in respect of cumulative profitability Gini Fabrics is the best. On the other hand, regarding debt paying capacity Siyaram is the best. In retail sector highest credit score captured by Gini Fabrics and it followed by Raymond, Siyaram, Bata and Titan in that order.

\section{Table 14}

Ranking on the basis of credit scores of the selected companies of retail sector

\begin{tabular}{cccccc} 
RATIO/ & & & & \\
COMPANIES & BATA & SIYARAM & GINI & RAYMOND & TITAN \\
\hline X1 & 0.102 & 0.075 & 0.111 & 0.057 & 0.206 \\
X2 & 1.264 & 2.736 & 4.917 & 3.469 & 0.709 \\
X3 & 0.168 & 0.588 & 0.541 & 0.46 & 0.293 \\
X4 & 44.38 & 225.1 & 179.1 & 166.6 & 72.21 \\
X5 & 1.536 & 3.435 & 5.929 & 4.4 & 0.771 \\
X6 & 276.2 & 241.6 & 659 & 548.3 & 134.3 \\
X7 & 2.522 & 7.346 & 6.18 & 6.853 & 2.847 \\
X8 & 1.286 & 4.888 & 5.166 & 0.747 & 1.869 \\
\hline TOTAL AVG SCORES & 327.5 & 485.8 & 861 & 730.9 & 213.2 \\
CREDIT SCORES(CS) & 40.94 & 60.73 & 107.6 & 91.36 & 26.65 \\
RANKING & 4 & 3 & 1 & 2 & 5 \\
\hline
\end{tabular}

In Table 14, sector wise ranking and ranking on the basis of companies as a whole have been done regarding their credit score. In sector wise ranking Gini Fabrics captured the top most position in retail sector. Table 14 depicts that in Retail sector the ratio $\mathrm{x}_{4}$ in Bata, Siyaram, Gini Fabrics, Raymond and Titan are 44.38, 225.31, 179.1, 166.6 and 72.21 respectively. On the other hand the ratio $\mathrm{x}_{6}$ in Bata, Siyaram, Gini Fabrics, Raymond and Titan are 276.2, 241.6, 659, 548.3 and 134.3 respectively. Ratio $\mathrm{x}_{4}$ is highest in Siyaram while ratio $\mathrm{x}_{6}$ is highest in Gini Fabrics. Ratio $\mathrm{x}_{6}$ of Gini Fabrics and high positive ratio $\mathrm{x}_{4}$ helped the Gini Fabrics to capture the top most position in Retail sector as well as all the companies taken together.

Table 15

Analysis of liquidity position of retail sector

\begin{tabular}{cccccc}
\hline & & & & \multicolumn{2}{c}{ NWC/ } \\
COMPANIES & CA & CL & AVG CASH as \% OF CA & CL \% OF CA & CREDIT EXPOSURE \\
\hline BATA & 414.247 & 193.32 & 0.023863 & 0.462715798 & 44.37602971 \\
SIYARAM & 221.557 & 42.903 & 0.007143 & 0.184097076 & 225.1171739 \\
GINI & 8.212 & 2.607 & 0.076895 & 0.306699549 & 179.0710795 \\
RAYMOND & 838.962 & 270.72 & 0.030401 & 0.317251487 & 166.5645674 \\
TITAN & 1171.812 & 685.21 & 0.063327 & 0.494203443 & 72.20645628 \\
\hline
\end{tabular}

Table 15 shows that in Retail sector, the liquidity ratio $\left(\mathrm{x}_{4}\right)$ as per our model in Bata is 44.37 whereas its current liabilities consist of $46.27 \%$ of current assets and at the same time cash occupied $2.38 \%$ of current assets. The liquidity ratio $\left(\mathrm{x}_{4}\right)$ as per our model in Siyaram is 225.11 whereas its current liabilities consist of $18.40 \%$ of current assets and at the same time cash occupied $0.71 \%$ of current assets. Similarly, the liquidity ratio $\left(\mathrm{x}_{4}\right)$ as per our model in Gini Fabrics is 179.07 whereas its current liabilities consist of $30.66 \%$ of current assets and at the same time cash occupied $7.68 \%$ of current assets. In Raymond the liquidity ratio $\left(\mathrm{x}_{4}\right)$ as per our model is 166.56 whereas its current liabilities consist of $31.72 \%$ of current assets and at the same time cash occupied $3.04 \%$ of current assets. The liquidity ratio $\left(\mathrm{x}_{4}\right)$ as per our model in Titan is 72.20 whereas its current liabilities consist of $49.42 \%$ of current assets and at the same time cash occupied $6.33 \%$ of current assets. Therefore, from Table 15 
we can conclude that lower portion of current liabilities consist in current assets and low cash balance in current assets help to increase the liquidity ratio of Siyaram. In general, all the companies under study in retail sector maintained moderate portion of current liabilities in current assets.

Coefficient of Correlation is the measurement of degree of association between two variables. A positive value of ' $r$ ' indicated high values of one variable are generally associated with the high values of other variables and low values with low values. In this study multiple correlation technique among Cash as a \% of CA, CL as a \% of CA and NWC/Credit Exposure has been applied. To test the significance of such coefficient, ' $t$ ' test has been used.

Table 16

Correlation Analysis of Retail Sector

\begin{tabular}{llccc}
\hline & & Cash of CA & CL of CA & NWC of CR EXP \\
\hline \multirow{3}{*}{ Cash of CA } & Pearson correlation & 1 & .391 & -.187 \\
& Sig. (2-tailed) & & .515 & .763 \\
& N & 5 & 5 & 5 \\
\hline \multirow{3}{*}{ CL of CA } & Pearson correlation & .391 & 1 & $-.966^{* *}$ \\
& Sig. (2-tailed) & .515 & 5 & .007 \\
& N & 5 & 5 & 5 \\
\multirow{3}{*}{ NWC of CR EXP } & Pearson correlation & -.187 & $-.966^{* *}$ & .007 \\
& Sig. (2-tailed) & .763 & 5 & 5 \\
\hline
\end{tabular}

**. Correlation is significant at the 0.01 level (2-tailed).

Table 16 shows that in Retail sector the correlation analysis between cash as a percent of current assets is negatively related with liquidity $\left(\mathrm{x}_{4}\right)$. The correlation coefficient is statistically not significant. On the other hand, the correlation coefficient between current liabilities as a percent of current assets and liquidity ratio $\left(\mathrm{x}_{4}\right)$ is negative. The correlation coefficient is (-) 0.966 and it is statistically significant at $1 \%$ level. Here also the correlation coefficient between current liabilities as a percent of current assets and liquidity ratio $\left(\mathrm{x}_{4}\right)$ supported the theoretical principle that higher the current liabilities as percent of current assets lower the liquidity. The other correlation coefficient in between cash as a percent of current assets and current liabilities as a percent of current assets is positive, which is 0.391 and it is not statistically significant.

From the table it is seen that in Asian, Wipro, Videocon in IT sector; Khaitan in Consumer Durable sector, all the Pharmaceuticals companies selected under study, Britannia in FMCG sector, Siyaram, Gini Fabrics and Raymond in Retail Sector, credit score are above standard (58.32).In these companies current liabilities as a percent of current assets is very low except in case Alchemist and Khaitan. In these two companies strong equity base leads to high comfort margin and helps to increase their credit rating. But in other companies, whose credit scores are above standard, the low proportion of current liabilities helps to achieve very high liquidity score of the companies as well as strong equity base of those companies leads to very high comfort margin and ultimately increase their credit rating.

\section{Conclusion}

Management of current assets and current liabilities is popularly known as liquidity management. It emphasizes to maintain current assets in such a way that it can meet the current liabilities timely. For meeting the short term debt timely, many firms takes the opportunity of external funding. But, the firm cannot collect such external financing easily, particularly in case of small firms. External financing is very costly for small firms. So, the efficient liquidity management of the company helps its long-term prosperity and healthy bottom lines and more specifically to make the company remain solvent. Cash Conversion Cycle (CCC) is such a useful technique by which we can easily and quickly assess the liquidity of the firm. It invariably measures the time lag between cash payments for purchase of inventories and collection of receivables from customers. CCC is a dynamic measure of continuous liquidity management, which comprises both balance sheet and income statement data with time 
dimension. An individual firm's CCC is helpful but from industries stand point it is crucial for a company to evaluate its performance regarding $\mathrm{CCC}$ and assess opportunities for improvement because the length of CCC may differ from industry to industry. From the liquidity view point Gini Fabrics is the best. But, the relationship between CCC and ITR, CCC and CR, CCC and DTR, CCC and Debtors more than six months and CCC and CTR is to some extent not theoretically sound. Out of which some factors positively and some factors negatively influenced the CCC of all the companies selected in this study.

From the five companies from Retail sector Gini Fabrics maintained higher level of cash as \% of total assets throughout the study period and it helped the company to improve its liquidity position. From the point of view of average and consistency aspect together Raymond occupied the first rank. The correlation coefficients between ACH and Size of the Organization and ACH and Investment of most of the companies are positive. The impact of DFL on ACH and Investment on ACH of most of the companies is negative, whereas the impact of Size of the organization on ACH of most of the companies is positive. Only Raymond supported most of the theoretical propositions among the companies selected in this study.

Credit Score signifies the creditworthiness of the company. Higher CS signifies better creditworthiness and vice-versa. Higher creditworthiness gives the opportunity to the company for late payment and late payment increases the deferral period. It again decreases the cash conversion cycle. Lower CCC represents less requirement of working capital. So liquid cash are not blocked in other types of current assets, it can invest in some profitable project to enhance profit. Hence good creditworthiness indirectly increases the profitability of the organization. From another point of view creditworthiness helps the company for achieving higher debtors' turnover. As the credit manager takes the decision of granting credit before the commencement of sales then it helps the organization to take decision regarding its future investment projects. It helps the management to know how and when money should be collected and such information protect the company to borrow funds for investing future profitable projects. It also minimizes the CCC of the organization which indirectly increases the profit of the organization.

In this study we observed that from the view point of average and consistency of CCC Bata is the best and it follows by Gini Fabrics whereas in consistency of cash as a \% of total assets, Raymond is ranked first and it follows by Gini Fabrics, Titan and Bata. And from the credit score point of view Gini Fabrics is the best and it follows by Raymond, Siyaram and Bata. It signifies that due to higher credit score, the said companies managed to decrease their CCCs.

\section{References}

Baskin, J. B., \& Miranti Jr, P. J. (1999). A history of corporate finance. Cambridge University Press.

Bathory, A. (1987). Analysis of Credit: Foundations and Development of Corporate Assessment. McGraw-Hill Inc., US.

Basu, A. (2011). Ratio based credit evaluation model. International Journal of Research in Commerce, IT and Management. 1(1).

Bodie, Z., \& Merton, R. C. (2002). International pension swaps. Journal of Pensions Economics \& Finance, 1(01), 77-83.

Chiou, J. R., Cheng, L., \& Wu, H. W. (2006). The determinants of working capital management. Journal of American Academy of Business, 10(1), 149-155.

Das, S. (2014). Creditworthiness is a technique of cash management - A study on IT sector. International Journal of Business Analytics \& Intelligence, 2(2), 37-46.

Deloof, M. Jegers, M. (1996). Trade credit, product quality, and intra-group trade: some European evidence. Financial Management, 25(3), 33.

Dittmar, A., \& Mahrt-Smith, J. (2007). Corporate governance and the value of cash holdings. Journal of Financial Economics, 83(3), 599-634.

Dittmar, R. F. (2002). Nonlinear pricing kernels, kurtosis preference, and evidence from the cross section of equity returns. Journal of Finance, 57 (1), 369-403. 
Farris II, M. T., Hutchison, P. D., \& Hasty, R. W. (2011). Using cash-to-cash to benchmark service industry performance. Journal of Applied Business Research (JABR), 21(2).

Ferreira, M. A., \& Vilela, A. S. (2004). Why do firms hold cash? Evidence from EMU countries. European Financial Management, 10(2), 295-319.

Guney, Y., Ozkan, A., \& Ozkan, N. (2003). Additional international evidence of corporate cash holdings. Working paper. University of York.

Jordan, J., Lowe, J. and Taylor, P. (1998). Strategy and financial policy in UK small firms. Journal of Business Finance \& Accounting, 25(1/2), 1-27.

Kalcheva, I., \& Lins, K. V. (2007). International evidence on cash holdings and expected managerial agency problems. Review of Financial Studies, 20(4), 1087-1112.

Keown, A. J. (2003). Foundations of finance: The logic and practice of financial management.

Kim, C.-S., Mauer, D.C., \& Sherman, A.E. (1998). The determinants of corporate liquidity: Theory and Evidence. Journal of Financial and Quantitative Analysis, 33, 305-334.

Moss, J. D., \& Stine, B. (1993). Cash conversion cycle and firm size: a study of retail firms. Managerial Finance, 19(8), 25-34.

Myers, S. C. (1977). Determinants of corporate borrowing. Journal of Financial Economics, 5(2), $147-$ 175.

Myers, S. C., \& Majluf, N. S. (1984). Corporate financing and investment decisions when firms have information that investors do not have. Journal of financial economics, 13(2), 187-221.

Opler, T., Pinkowitz, L., Stulz, R., \& Williamson, R. (1999). The determinants and implications of corporate cash holdings. Journal of Financial Economics,52(1), 3-46.

Padachi, K. (2006). Trends in working capital management and its impact on firms' performance: an analysis of Mauritian small manufacturing firms. International Review of Business Research Papers, 2(2), 45-58.

Richards, V. D., \& Laughlin, E. J. (1980). A cash conversion cycle approach to liquidity analysis. Financial Management, 9(1), 32-38.

Saccurato, F. (1994). The study of working capital. Business Credit, 96(1), 36-37.

Saddour, K. (2006). The determinants and the value of cash holdings: Evidence from French firms. Cahier de recherche $n, 6$.

San-Jose, L., Iturralde, T., \& Maseda, A. (2008). Treasury management versus cash management. Available at SSRN 1088015. 